DOI: https://doi.org/10.24297/jssr.v15i.8554

\title{
The Mediating Effect on Self-Efficacy in The Relationship Between Gender Identity and Leadership Style
}

\author{
Sabine Pohl, Pascale Desrumaux, Anne-Marie Vonthron \\ Université Libre de Bruxelles
}

spohl@ulb.ac.be, pascale.desrumaux@univ-lille.fr, anne-marie.vonthron@u-paris10.fr

\begin{abstract}
According to role congruence theory (Eagly \& Karau, 2002), it is not the evaluative content of the stereotype of women but its mismatch with leadership roles that underlies women discrimination with regards to leadership roles. The current study sought to establish whether leaders gender identity or the extent to which the leader possesses traits associated with traditional gender stereotypes may explain leadership styles. Using a sample of 163 managers working within the bank and personal care services, results show that among both male and female leaders, masculine gender identity was more strongly related to group-focused transformational leadership (charisma, inspirational motivation, and idealized influence), transformational intellectual stimulation leadership and to transactional leadership styles. Furthermore, the results show that masculine leadership selfefficacy mediates the relationship between gender identity and leadership styles. Results are discussed in relation to previous research.
\end{abstract}

\section{Introduction}

Despite the increasing numbers of women in the workforce, few females occupy a management position (Balasubramanian \& Lathabhavan, 2018). Most studies indicate that the ideal manager is perceived as possessing stereotypical 'masculine' traits such as self-confidence, independence, assertiveness, dominance and rationality (Kark, Waismel-Manor, \& Shamir, 2012). According to role congruence theory (Eagly \& Karau, 2002), it is the incongruity with leadership roles that underlies women discrimination with regard to leadership roles. The extent to which the leader possesses characteristics associated with gender stereotypes may explain leadership behaviors.

This study aims to make the following contributions to the field: First, according to role congruence theory, masculine gender identity is demonstrably related to leadership behaviors. Secondly, this study shows that leadership self-efficacy is an important motivational mechanism that connects gender identity to leader behaviors.

\subsection{Gender Stereotypes, Gender Roles and Gender Identity}

Gender stereotypes are the shared beliefs about supposed psychological or behavioural traits characteristic of each sex (Scott \& Brown, 2006). The male stereotype is characterized by 'masculine' characteristics such as dominance, independence, and achievement, whereas the female stereotype is characterized, by 'feminine' characteristics such as empathy, caring, and affiliation (Eagly, Wood, \& Diekman, 2000). According to male ratings, there is a positive correlation between the concept of man and the concept of leadership, which contrasts with the negative correlation when considering the concept of woman and the concept of leadership (Kolb, 1999).

According to Kolb (1999), perceptions of leadership and adoption of leadership styles are linked to stereotyped perceptions of gender roles. Gender roles can be conceptualised as consensual beliefs about the attributes of women and men. Eagly (1987) observed that "These beliefs are more than beliefs about the attributes of women and men: Many of these expectations are normative in the sense that they describe qualities or behavioural 
tendencies believed to be desirable for each sex" (p. 13). Gender role refers to both descriptive and prescriptive expectations related to women and men (Eagly \& Karau, 2002).

Gender roles derive from gender identities (Stryker \& Burke, 2000). Gender identity consists in the extent to which an individual believes that he or she possesses traits associated with traditional gender stereotypes (Bem, 1993). Individuals who have a masculine gender identity perceive themselves as assertive, dominant, and competitive (Eagly \& Karau, 2000). Individuals with a feminine gender identity perceive themselves as empathic, friendliness, and concerned for others (Eagly et al., 2000). Gender identities are internalized gender roles expectations (Stryker \& Burke, 2000).

\subsection{Transactional and Transformational Leadership and Gender Identity}

In investigating relationships between gender identity and leadership styles, we focus on the full range of the leadership paradigm (Avolio \& Bass, 1991) that differentiates between transformational and transactional leadership styles.

Transformational leaders inspire subordinates to adopt creative solutions to problems. They serve as models and foster trust and enthusiasm for their vision of the future (Vinkenburg, van Engen, Eagly, \& JohannesenSchmidt, 2011). Transformational leadership comprises the following four factors. (a) The idealized influence concern charisma, the power, the self-confidence, and ethics of a leader. c) Inspirational motivation refers to how leaders might strengthen their subordinates by viewing the future with optimism, emphasizing striving goals, offering a shared vision. d) Intellectual stimulation refers to a leader who challenges followers to find creative solutions to problems. e) Individualized consideration refers to a leader's behavior contributing to follower satisfaction by advising, supporting, and paying attention to them (Antonakis, Avolio, \& Sivasubramaniam, 2003).

Transactional leadership establishes with these subordinates exchange relationships (Vinkenburg et al., 2011). Transactional leaders, appeal to subordinates' self-interest by establishing an exchange relationship (Bass, 1998). There are three dimensions to transactional leadership: (a) Contingent reward leadership when a leader's actions are centred on clarifying objectives, task requirements and rewarding subordinates for a job well done; (b) management-by-exception active concerns the actions of a leader whose goal is to ensure that standards are met; and (c) management-by-exception passive refers to leaders who only intervene after noncompliance or mistakes have occurred (Antonakis et al., 2003). Wu, Tsui, and Kinicki (2010) suggest to regroup charisma, idealized influence and inspirational motivation in group-focused leadership because these behaviors aim to influence a group as a whole by creating shared values and promoting a shared mission. Although transformational and transactional leadership are conceptually and empirically separate, they both present effective leaders (Eagly, Johannesen-Schmidt, \& Van Engen, 2003).

According to social role identity, leaders adopt behaviors that are congruent with gender-role expectations. Perceivers make an inference about the congruence between the types of actions people engage in and their gender role (Desrumaux \& Pohl, 2014). The ability to predict from role identity to performance is higher for those with more committed identities (Stryker \& Burke, 2000).

As Eagly et al. (2000) argued, the influence of gender roles on leadership style occurs because most people have internalized their gender roles. The gender identity of leaders reflects an introjection of their gender role (Eagly et al., 2003). A study investigating the relationship between gender-role characteristics and transformational leadership showed that some components of transformational managers were perceived as characterized by 'feminine' characteristics more than by 'masculine' ones (Klark et al., 2012). Vinkburg et al. (2010) showed that individualized consideration was perceived as more important for women than men with regards to promotion. However, previous studies argue that the dominant traits associated with transformational leadership are masculine and are socially ascribed to men in our culture (Ford, 2006). Charisma, inspirational motivation, and idealized influence, reflect ambition and assertiveness that are considered as more acceptable in men than women (Prentice \& Carranza, 2002). These mixed results suggest that it is important to examine the relationship 
between gender identity and the transformational leadership style. Transactional leadership is more often associated with men than women (Eagly et al., 2003).

The discussion above provided the basis for the following hypothesis:

Hypothesis 1: Masculine gender identity was positively associated with group-focused transformational leadership (charisma, inspirational motivation, and idealized influence)

Hypothesis 2: Masculine gender identity was positively associated with transformational intellectual stimulation leadership

Hypothesis 3: Masculine gender identity was positively associated with transactional leadership styles

Hypothesis 4: Feminine gender identity was positively associated with individualized consideration leadership styles

\subsection{Leadership self- efficacy as a mediator}

According to social cognitive theory, self- efficacy refers to the "beliefs in one's capabilities to organize and execute the courses of action required to produce given attainments" (Bandura, 1997, p. 3). Self-efficacy influences the choices individuals make, their efforts, and how long they persevere when challenged (Bandura, 1997). Self-efficacy expectations are a motivational construct: the expectations that individuals have about their capacities to complete a task or tasks related to a specific goal. It results from the acquisition of cognitive or social skills through personal and/or vicarious experience (Bandura, 1997). There is a strong relationship between self-efficacy and actual task activity (Javidan, Bullough, \& Dibble, 2016). Leadership self-efficacy refers to a selfperceived capacity to successfully manage a group (Dickerson \& Taylor, 2000). The belief in one's leadership abilities shows positive responses (Hoyt $\&$ Blascovich, 2010). Several authors have suggested the importance of self-efficacy in the context of leadership (Javidan, Bullough, \& Dibble, 2016).

Leader self-efficacy is an important leadership "driver". Individuals with high leadership self-efficacy showed more interest in leadership-related tasks, whereas individuals who had low leadership self-efficacy were more likely to avoid leadership tasks (Dickerson \& Taylor, 2000).. Self-efficacy is viewed as an indicator of positive core evaluations (Judge \& Bono, 2001). According to role congruity theory (Eagly, 1987), it is the incongruity between stereotypes of women and the stereotype of leaders that produces bias evaluation (Heilman, 2012). The lackof-fit model suggests that an individual whose role is unreliable with the traits ascribed to him/her is discriminated against because of the perceived lack of fit, producing increased beliefs of failure and decreased beliefs of success (Desrumaux \& Pohl, 2014; Eagly \& Diekman, 2005). The incongruity between feminine gender identity and group focused transformational leaders and transactional leadership is one type of lack of fit. These processes can induce a decrease of leadership self-efficacy. The congruence between masculine gender identity and group focused transformational leaders and transactional leadership can lead to a positive association between gender identity and leadership self-efficacy.

Building on this analysis, we argue that self-efficacy is a mediator through which gender identity affects leadership styles.

Hypothesis 5: Leadership self-efficacy mediates the positive relationship between masculine gender identity and group-focused transformational leadership (charisma, inspirational motivation, and idealized influence).

Hypothesis 6: Leadership self-efficacy mediates the positive relationship between masculine gender identity and intellectual stimulation transformational leadership

Hypothesis 7: Leadership self-efficacy mediates the positive relationship between masculine gender identity and transactional leadership 
Hypothesis 8: Leadership self-efficacy mediates the positive relationship between feminine gender identity and individual consideration transformational leadership

\section{Method}

\subsection{Participants and Design}

The study used a cross-sectional survey questionnaire. Participants were asked to fill out a paper-and-pencil survey voluntarily. Participants returned their completed questionnaires directly to the research group.

Data were obtained from 163 managers working within bank and personal care services in Belgium. 50 per cent of the sample was male. Most of the participants (114) were between the ages of 40 and 65.

\subsection{Measures}

Gender identity: The gender identity was assessed using the Delignières \& Matkowski (2007) inventory. This inventory is a French validation and adaptation of the short version of the Bem Sex-Role Inventory (Bem, 1981), which is the most commonly used measure of stereotypical gender perceptions. Respondents rated the extent to which 10 masculine items and 10 feminine items described themselves on a 5 -point scale $(1=$ never or almost never true, $5=$ always or almost always true). The masculine items were averaged to yield a masculinity score, and the feminine items were averaged to yield a femininity score.

To create the gender-role identity score, we used continuous scores on the 'masculinity' and 'femininity' scales.

Transformational and transactional leader behavior. We used the Multifactor Leadership Questionnaire (MLQ) to assess leadership styles. The MLQ was the most widely used survey instrument to assess transformational and transactional leadership (MLQ) (Antonakis, et al, 2003). The MLQ contains 45 items. There are 36 items on the following nine behavioral components: Charisma, Inspirational Motivation, Idealized Influence, Individualized Consideration, Intellectual Stimulation (i.e., each leadership scale is comprised of four items), Contingent Reward, Management by Exception (active), Management by Exception (passive) and Laissez-Faire. Nine items assess leadership effectiveness. We adopt Wu et al.'s (2010) behavioral foci of transformational leadership, that is, individual-focused leadership and group-focused leadership. Individual-focused leadership adapts its behavior based on subordinates' individual differences (e.g., competences). Individual-focused leadership

concerns individualized consideration and intellectual stimulation. Group-focused leadership includes idealized influence and inspirational motivation and aims at influencing the group as a whole by creating shared values and seeking a common mission.

Leadership self-efficacy. Consistent with Bandura (1986), the construct of leadership self-efficacy should be measured with regards to specific job leadership behavior. We used the Self-efficacy Follenfant Scale (Follenfant \& Meyer, 2003). The Follenfant scale contains ten items rated on a 5-point Likert scale. Participants indicate their confidence in their ability to successfully complete the given tasks, with 1 indicating that they have no confidence at all in completing the task, and 5 indicating that they are completely confident they can complete the task. The items are averaged for a total Leadership Self-Efficacy score.

Demographic information. Participants reported their sex, age, sector and years of management experience

Controlled variables: We controlled for sex as this variable has been found to be related to leadership styles (Koenig, Eagly, Mitchell, \& Ristikari, 2011).

\subsection{Ethical considerations}


The study conforms to the Code of Ethics of the World Medical Association (Declaration of Helsinki). Participants were informed about the study's purpose. They were informed that their anonymity was assured. Informed consent was assured when participants returned filled-out questionnaires.

\section{Results}

\subsection{Descriptive statistics}

Table 1: Means, standard deviations, internal consistency reliabilities, and correlations

\begin{tabular}{|c|c|c|c|c|c|c|c|c|c|}
\hline & $\mathbf{M}$ & SD & 1 & 2 & 3 & 4 & 5 & 6 & 7 \\
\hline 1. Masculine gender identity & 2,71 & 59 & $(.936)$ & & & & & & \\
\hline 2. Feminine gender identity & 2,93 & ,49 &,- 009 & $(.925)$ & & & & & \\
\hline 3. Leadership self efficacy & 3,47 & ,72 &, $519 * * *$ &,- 017 & $(.949)$ & & & & \\
\hline 4. Transactional leadership & 2,83 & ,49 &, $451^{* * * *}$ & 012 &, $311 * * *$ & $(.809)$ & & & \\
\hline $\begin{array}{l}\text { 5. Transformational } \\
\text { Group-focused leadership }\end{array}$ & 3,39 & ,64 &, $505^{* * *}$ &,- 031 &, $790 * * *$ &, $408 * * *$ & $(.906)$ & & \\
\hline $\begin{array}{l}\text { 6. Transformational Intellectual } \\
\text { stimulation }\end{array}$ & 3,5 &, 74 &, $358 * * *$ &,- 097 &, $771 * * *$ &, $339 * * *$ &, $835 * * *$ & $(.855)$ & \\
\hline $\begin{array}{l}\text { 7. Transformational Individual } \\
\text { consideration }\end{array}$ & 3,63 &, 72 &, $280 * * *$ &, 051 &, $750 * * *$ &, $241 * *$ &, $817 * * *$ &, $814 * * *$ & $(.820)$ \\
\hline
\end{tabular}

Note: $* * * p<.000 ; * * p<.01$

Means, standard deviations, internal consistency reliabilities, and intercorrelations for all the variables are presented in Table 1. As can be seen, all variables displayed good internal consistency $(\cdot \mathrm{s}>.70)$.

\subsection{Test of hypothesis}

Multiple regression analysis, with controls, entered at step 1 (sex) and masculine gender identity and feminine gender identity in step 2. The significance of indirect effects was further tested using a bootstrap analysis (MacKinnon, Lockwood, \& Williams, 2004).

Table 2 : Results of regression analysis on gender identity on leadership styles

\begin{tabular}{lllll}
\hline & $\begin{array}{l}\text { Transformational } \\
\text { Group-focused } \\
\text { leadership }\end{array}$ & $\begin{array}{l}\text { Transformational } \\
\text { Intelectual } \\
\text { stimulation }\end{array}$ & $\begin{array}{l}\text { Transformational } \\
\text { Individual } \\
\text { consideration }\end{array}$ & $\begin{array}{l}\text { Transactional } \\
\text { leadership }\end{array}$ \\
\hline $\begin{array}{l}\text { Model1 } \\
\text { Tenure }\end{array}$ &, $536^{* * *}$ &,$- 227^{* *}$ &,,$- 246^{* *}$ &, 132
\end{tabular}

Model 2

$\begin{array}{lllll}\text { Masculine gender identity } & , 588 * * * & , 299 * * * & , 211 * * * & , 463 * * * \\ \text { Feminine gender identity } & -, 055 & -, 014 & , 151 * * & -, 004 \\ \text { Sexe } & , 033 & , 126 & , 163 * & , 045\end{array}$

Model 3

$\begin{array}{lllll}\text { SexeXIGM } & -, 115 & -, 011 & -, 193 * * & , 084 \\ \text { SexeXIGF } & , 065 & -, 028 & -, 067 & , 049\end{array}$

R2

Note. $* * * p<.000 ; * * p<.01$

As can be seen from Table 2, support is found for Hypothesis 1,2 and 3, demonstrating a positive relationship between masculine gender identity and transformational group-focused leadership $(\because . .512 ; p<.000)$, transformational intellectual stimulation $(\because .373 ; p<.000)$ and transactional leadership $(\cdot: 290 ; p<.000)$. Results do not support hypothesis 4 , which predicted that feminine gender identity was positively related to individual consideration $(\because: 0.037 ; p>.000)$.

\subsection{Leadership self-efficacy as a mediator}


To further test Hypotheses 5-8 (the four mediation hypotheses), we performed the Sobel test, which provides a test of the indirect effect of an independent variable on the dependent variable via the mediator (MacKinnon, Lockwood, Hoffman, West, \& Sheets, 2002). Data was analysed using the method suggested by Preacher and Hayes (2004) in the case of mediator analyses. We adopted bootstrapping to derive better estimates. The use of bootstrapped confidence intervals avoids power problems of asymmetry and non-normal sampling distributions of an indirect effect (MacKinnon, Lockwood, \& Williams, 2004).

Results indicated that the indirect effects of masculine gender identity on transformational group-focused leadership (z: .6.55; $p<.01)$, on intellectual stimulation transformational leadership $(\mathrm{z}: .6 .63 ; p<.01)$ and on individual consideration leadership ( $\mathrm{z}$. $6.55 ; p<.01$ ) were significant. The results supported Hypotheses 5,6 , and 7. Results provide evidence of a mediating role for leadership self-efficacy in the relationship of masculine gender identity to the three dimensions of transformational leadership. Leadership self-efficacy does not mediate gender identity-transactional leadership linkage $(z: .1,27 ; p>.05)$. Next, we tested the mediated effect of leadership self-efficacy on the relationship between feminine gender identity and individual consideration transformational leadership. This revealed that leadership self-efficacy does not mediate this relationship (z: ,30; $p>.05)$.

\section{Discussion}

The first aim of this research is to broaden the focus of previous investigations by examining the effects of gender stereotypes on leadership style and by offering new insights into the relationship between gender identity and the adoption of certain manager styles. Previous studies indicate that women, in contrast to men, have greater difficulties in attaining top leadership roles, and are less evaluated than male leaders (Hoyt $\&$ Blascovich, 2010). The findings of this research both support previous research and develop our understanding of the mechanisms through which gender identity affects transactional and transformational leadership. Two key findings are discussed:

Firstly, we found masculine gender identity to be significant predictors of transactional and transformational leadership styles. More precisely, this result provides empirical support for the idea that masculine gender identity has a positive impact on group-focused and intellectual transformational leadership. This finding suggests that the actual behavior of male and female leaders is generally consistent with gender role stereotypes. These gender role stereotypes may be limiting the behavioral choices available to men and women in leadership roles.

Second, the relationship between masculine gender identity and transformational leadership was found to be mediated by leadership self-efficacy. Results show that self-efficacy is more strongly associated with the adoption of a transformational leadership style than with the adoption of a transactional leadership style. Transformational leadership is associated with the leader's evaluation of his/her own abilities and capacity to manage challenges in the workplace (Nielsen et al, 2009). Leadership self-efficacy is essential to the transformational leadership process because it affects the objectives a leader selects and competences. Masculine gender identity is associated with a more important leadership self-efficacy than female gender identity. Leaders with feminine gender identity will not develop the same belief in their leadership capabilities than a leader with a masculine gender identity.

This finding suggests a promising avenue of research exploring self-efficacy based interventions to enhance transformational leadership.

\section{Limitations and implications}

There are a number of theoretical and practical implications of this study. As with all research, this study has limitations. The data were gathered at one point in time, making it impossible to draw inferences of causality. Drawing on longitudinal designs may help to further our understanding of the direction of the relationships between gender identity, self-efficacy, and leadership style and provide further validation of these relationships. 
Leadership style and leadership self-efficacy were based on self-reports. Nevertheless, the fact that leaders' selfratings have less validity than others' ratings of leaders, is debatable. The results of Malloy and Janowski (1992) study shows that self and other perceptions of leadership style appeared to be similar.

This study sheds no light on how the organizational context influence the perceptions of self-efficacy. Yeagley, Subich, and Tokar (2010) suggested that self-efficacy is formed in the context of other background experiences, culture, and contextual affordances. Further exploration of the contextual influences that may affect leadership self-efficacy may add important information.

Finally, gender identity is treated as a characteristic of the individual, whereas more comprehensive contextual patterns that can lead to gender identity are not considered. Previous studies have shown that gender becomes effectively salient in organizational contexts that are gender-typed. When gender identity is effectively salient in an organizational context, it is biased with regards to the extent to which a woman, compared to a similar man, infers about her abilities to perform tasks (Ridgeway \& Correll, 2004). The study of models, including contextual characteristics, clarifies the relationship between gender identity and leadership.

Stereotypes of managers have consequences (discrimination, beliefs...) that may include a bias against choosing and promoting women to management positions. For example, past studies have consistently shown that the gender typicality of applicants' faces affects hiring decisions for leadership positions irrespective of applicants' gender (Desrumaux \& Pohl, 2014 ). Being aware of biasing influences caused by gender identity or by masculine vs. feminine appearance is very important, and managers and decision-makers need to receive training about bias and assessment. This training should focus on stereotypes, showing, for instance, the many cases of women succeeding in managerial positions. Furthermore, leadership self-efficacy doesn't appear automatically amongst individuals (It is necessary to understand that we are not "naturally" a manager of a team but become a manager because of our abilities, and self-efficacy.

\section{Sources of funding}

This research received no specific grant from any funding agency in the public, commercial, or not-for-profit sectors.

\section{Conflict of Interest}

No conflict of interest has been declared by the authors.

\section{References}

1. Antonakis, J., Avolio, B. J., \& Sivasubramaniam, N. (2003). Context and leadership: An examination of the ninefactor full-range leadership theory using the Multifactor Leadership Questionnaire. The Leadership Quarterly, 14(3), 261-295. doi:10.1016/S1048-9843(03)00030-4

2. Avolio, B. J. \& Bass, B. M. (1991). Manual for the full range of leadership. Binghamton, N.Y: Bass, Avolio \& Associates. doi.: 10.1177\%2F014920639101700303

3. Balasubramanian, S.A. and Lathabhavan, R. (2018) Linking women's glass ceiling beliefs and employee satisfaction: the mediation of engagement, Int. J. Human Resources Development and Management, 18,7290. doi: $10.1504 /$ IJHRDM.2018.092287

4. Bandura, A. (1997). Self-efficacy: The exercise of control. New York: Freeman.

5. Bass, B. M. (1998). Transformational leadership: Industrial, military, and educational impact. Mahwah, NJ: Lawrence Erlbaum. 
6. Bem, S. L. (1993). The lenses of gender: Transforming the debate on sexual inequality. NewHaven: Yale University Press.

7. Delignières, Didier et Matkowski, S., « Une version courte de l'inventaire des rôles sexués de Bem », in Vlle Congrès International de I'ACAPS, Marseille, 3-5 1997, http://pagespersoorange.fr/didier.delignieres/Colloques-docs/MARS-D1.pdf

8. Desrumaux, P., \& Pohl, S. (2014). Juger la recrutabilité des candidats: Quels effets de l'apparence et des aptitudes en fonction des types de postes? Psychologie Française. doi :10.1016/j.psfr.2013.12.001

9. Dickerson, A., \& Taylor, A. (2000). Self-limiting behavior in women: Self-esteem and self-efficacy as predictors. Group \& Organization Management, 25, 191-210.

10. Eagly, A. H. (1987). Sex differences in social behavior: A social role interpretation. Hillsdale, NJ: Erlbaum.

11. Eagly, A.H., Wood, W., Diekman, A.B., (2000). Social role theory of sex differences and similarities: A current appraisal. In T Eckes, H. M. Trautner (Eds.), The developmental social psychology of gender (pp. 123-174). Erlbaum, Mahwah, NJ,

12. Eagly, A. H, Carli L. L. (2003). The female leadership advantage: An evaluation of the evidence. The Leadership Quarterly, 14, 807-834. doi: 10.1016/j.leaqua.2003.09.004.

13. Eagly, A. H., Johannesen-Schmidt, M. C., \& van Engen, M. (2003). Transformational, transactional, and laissezfaire leadership styles: A meta-analysis comparing women and men. Psychological Bulletin, 95, 569-591. doi: 10.1037/0033-2909.129.4.569

14. Eagly, A. H., \& Karau, S. J. (2002). Role congruity theory of prejudice toward female leaders. Psychological Review, 109(3), 573-598. doi: 10.1037//0033-295X.109.3.573

15. Follenfant, A., \& Meyer, T. (2003). Pratiques déclarées, sentiment d'avoir appris et autoefficacité au travail. Résultats de l'enquête quantitative par questionnaires. Les apprentissages professionnels informels. Paris: L'Harmattan, 185-246.

16. Eagly, A. H., \& Diekman, A. B. (2005). What is the problem? Prejudice as an attitude-in-context. On the nature of prejudice: Fifty years after Allport, 19-35.

17. Ford, J. (2006). Discourses of leadership: Gender, identity, and contradiction in a UK public sector organization. Leadership, 2(1), 77-99. doi: 10.1177/1742715006060654

18. Heilman, M. E. (2012). Gender stereotypes and workplace bias. Research in Organizational Behavior, 32, 113135. doi:10.1016/j.riob.2012.11.003

19. Hoyt, C. L., \& Blascovich, J. (2010). The role of leadership self-efficacy and stereotype activation on cardiovascular, behavioral, and self-report responses in the leadership domain. The Leadership Quarterly, 21(1), 89-103. doi.:10.1016/j.leaqua.2009.10.007

20. Javidan, M., Bullough, A., \& Dibble, R. (2016). Mind the gap: Gender differences in global leadership selfefficacies. Academy of Management Perspectives, 30(1), 59-73.

21. Judge, T. A., \& Bono, J. E. (2001). Relationship of core self-evaluations traits-self-esteem, generalized selfefficacy, locus of control, and emotional stability - with job satisfaction and job performance: A meta-analysis. Journal of Applied Psychology, 86(1), 80-92. doi.:10.1037/0021-9010.86.1.80 
22. Kark, R., Waismel-Manor, R., \& Shamir B. (2012). Does valuing androgyny and femininity lead to a female advantage? The relationship between gender-role, transformational leadership and identification. The Leadership Quarterly, 23, 620-640. doi:10.1016/j.leaqua.2011.12.012

23. Koenig, A. M., Eagly, A. H., Mitchell, A. A., \& Ristikari, T. (2011). Are leader stereotypes masculine? A metaanalysis of three research paradigms. Psychological Bulletin, 137(4), 616-642. doi: 10.1037/a0023557.

24. Kolb, J. A. (1999). The effect of gender role, attitude toward leadership, and self-confidence on leader emergence: Implications for leadership development. Human Resource Development Quarterly, 10(4), 305320. doi : $10.1002 /$ hrdq.3920100403

25. MacKinnon, D. P., Lockwood, C. M., Hoffman, J. M., West, S. G., \& Sheets, V. (2002). A comparison of methods to test mediation and other intervening variable effects. Psychological Methods, 7(1), 83-104. doi:10.1037//1082-989X.7.1.83

26. MacKinnon, D. P., Lockwood, C. M., \& Williams, J. (2004). Confidence limits for the indirect effect: Distribution of the product and resampling methods. Multivariate Behavioral Research, 39(1), 99-128. doi : $10.1207 / \mathrm{s} 15327906 \mathrm{mbr} 3901 \_4$

27. Malloy, T. E., \& Janowski, C. L. (1992). Perceptions and metaperceptions of leadership: Components, accuracy, and dispositional correlates. Personality and Social Psychology Bulletin, 18, 700-708. doi :10.1177\%2F0146167292186006

28. March E., van Dick R. \& Hernandez Bark A. (2016) Current prescriptions of men and women in differing occupational gender roles, Journal of Gender Studies, 25(6), 681-692, DOI: 10.1080/09589236.2015.1090303

29. McCormick M.J. (2001). Self-efficacy and leadership effectiveness: Applying social cognitive theory to leadership. Journal of Leadership \& Organizational Studies, 8 (1), 22-33.

30. Mehrad, A. (2019). Role of Conflict Management Styles on Managers' self-efficiency at Iranian Schools in Tehran Province. Journal of Social Science Research,14, 2321-1091. DOI: https://doi.org/10.24297/jssr.v14i0.8524

31. Nielsen, K., Yarker, J., Randall, R., \& Munir, F. (2009). The mediating effects of team and self-efficacy on the relationship between transformational leadership, and job satisfaction and psychological well-being in healthcare professionals: A cross-sectional questionnaire survey. International journal of nursing studies, 46(9), 1236-1244. https://doi.org/10.1016/j.jnurstu.2009.03.001

32. Pei Wang, Ya-Ping Yang, Chen-Hao Tan, Qin-Wei Chen \& Thomas Cantfort (2017) Gender Stereotype Activation versus Lexical Semantic Activation: An ERP Study, The Journal of General Psychology, 144:4 , 283 308 ,

33. DOI: $\underline{10.1080 / 00221309.2017 .1310714}$

34. Prentice, D. A., \& Carranza, E. (2002). What women and men should be, should not be, are allowed to be, and don't have to be: The contents of prescriptive gender stereotypes. Psychology of Women Quarterly, 26(4), 269-281.

35. Ridgeway, C. L., \& Correll, S. J. (2004). Motherhood as a status characteristic. Journal of Social Issues, 60(4), 683-700. doi.org/10.1111/j.0022-4537.2004.00380.x 
36. Scott, K., \& Brown, D. (2006). Female first, leader second? Gender bias in the encoding of leadership behavior. Organizational Behavior and Human Decision Making Processes, 101, 230-242. doi :10.1016/j.obhdp.2006.06.002

37. Sczesny, S., \& Kühnen, U. (2004). Meta-cognition about biological sex and gender-stereotypic physical appearance: Consequences for the assessment of leadership competence. Personality and Social Psychology Bulletin, 30, 13-21. doi: 10.1177/0146167203258831

38. Sczesny, S., Spreemann, S., \& Stahlberg, D. (2006). Masculine = competent? Physical appearance and sex as sources of gender-stereotypic attributions. Swiss Journal of Psychology, 65, 15-22. doi.:10.1024/14210185.65.1.15

39. Stryker, S., \& Burke, P. J. (2000). The past, present, and future of an identity theory. Social Psychology Quarterly, 284-297.

40. Vinkenburg, Cl. J., van Engen M, Eagly A.H. \& Johannesen-Schmidt M.C. (2011). An exploration of stereotypical beliefs about leadership styles: Is transformational leadership a route to women's promotion? The Leadership Quarterly, 22, 10-21. doi:10.1016/j.leaqua.2010.12.003

41. Wu, J. B., \& Tsui, A. S., \& Kinicki, A. (2010). Consequences of differentiated leadership in groups. Academy of Management Journal, 53. doi :10.5465/AMJ.2010.48037079

42. Yeagley E.E., Subich, L. M. \& Tokar D. M. (2010). Modeling college women's perceptions of elite leadership positions with social cognitive career theory. Journal of Vocational Behavior, 77, 30-38. doi :10.1016/j.jvb.2010.02.003 